\title{
H. J. STARLING
}

Hubert John Starling died at the age of 76. He was born in India, where his father was Clerk of the Crown in Bombay, and returned to England for his education at St. Paul's School, London. He entered Guy's Hospital in 1891, from which he graduated in 1897 and proceeded M.D. in 1899. Being the youngest son of the family, he was at Guy's several years later than his eldest brother, Ernest $\mathbf{H}$. Starling, the distinguished physiologist.

After holding house appointments at Guy's Hospital, Hubert Starling went as Civil Surgeon with the South African Field Force and served until invalided home with dysentery. He obtained the D.P.H. Cambridge in 1901 and in 1902 settled in general practice in Norwich, which was his home for the rest of his life. Amongst his activities he made a speciality of anæsthetics and was the first honorary anæsthetist to be appointed at the Norfolk and Norwich Hospital in 1911.

He was thus led to work at circulatory problems, which remained his chief medical interest. He recorded his observations on blood pressure with the mercury sphygmomanometer, and then passed

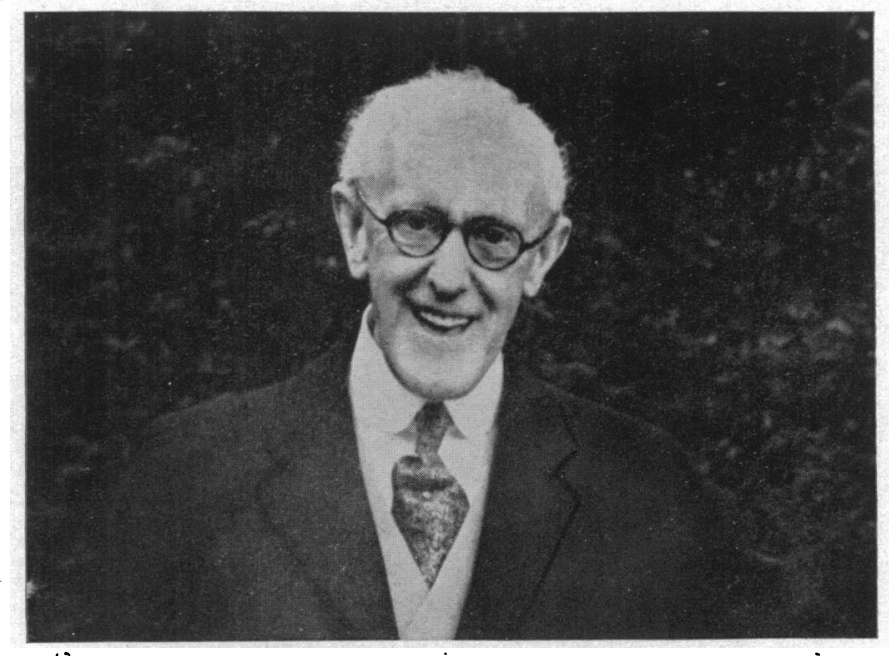

on to the MacKenzie polygraph. Starling was disappointed at being rejected for medical service in the first world war, but on the recommendation of MacKenzie and Lewis he was later appointed to the Military Heart Hospital at Colchester. Here he enjoyed the work and opportunities of making friends with cardiologists in Great Britain and overseas.

After the 1914-18 war he returned to Norwich, gave up his general practice, and became a consulting physician with leanings towards cardiology. He was one of the fifteen original members of the Cardiac Club. In 1926 he opened the discussion on angina pectoris and in 1929 on vaso-vagal attacks. He was appointed a physician to the Norfolk and Norwich Hospital and began a happy period of his life, marred only by fibrositis, attacks of which became more and more of a handicap. On retiring from hospital work, he continued his consulting work and during the second world war was active as Chairman of the Norwich medical board of the Ministry of Labour and National Service and he held this office till last year. Starling was very happy in his home life. He married a daughter of the late Dr. Thomas Fairbank of Windsor, and his wife took an active part with him 
in the musical and artistic interests centred in Norwich. Mrs. Starling's vagaries of health provided him with quite a lot of data for his researches and all his new gadgets were tried out on her. She was the willing cooperator, even patient victim, of his early experiments with blood-pressure apparatus, with the polygraph and with the electrocardiograph through the years.

This was the background in which Starling lived and worked, but it is necessary to try to appraise the man as known to his friends and the older members of the Cardiac Club. His early upbringing in the Catholic Apostolic Church and his training at Guy's made him an authoritarian; for him, medicine was an ordered cosmos and he was not attracted by novelties, which took some time for him to assimilate into the order of things: I remember in the early nineteen-twenties reporting on a case he sent for review that there was a calcified pericardium. He wrote back a long pungently expressed letter that it could not be as hed had consulted all the textbooks available and none mentioned calcified pericardium. Many years later he himself reported two or three cases of calcification of the pericardium from the Norfolk and Norwich Hospital. But Starling's years in general practice before becoming a consultant made him a sound and broad-minded physician. He remained didactic on ward rounds but mellowed with the years. His papers to the Cardiac Club read at a rapid rate with his slight lisp were sound but dogmatic, and in argument he would explode into his characteristic loud laugh, equally disconcerting whether as approbation or derision. Starling was best in a small group of three or four discussing patients; his case memory was accurate and his illustrations apposite. He liked to record his observations and the list of his publications appended shows the catholicity of his tastes and the breadth of his interests. He remembered with pleasure his association with colleagues at the Military Heart Hospital at Colchester in the first world war.

S. W. PATTERSON

\section{Major Publications}

1906 Observation on arterial blood-pressure in heart disease, Lancet, 2, 846.

1910 The value of blood-pressure determinations in toxæmia of pregnancy, Ibid, 2, 784.

1918 Subacute bacterial endocarditis, Brit. med. J., 2, 154.

1922 Endocarditis lenta, Quart. J. Med., 16, 263.

1923 Tonsillar and rheumatic infections, Guy's Hosp. Rep., 73, 388.

1930 Case of megacolon with unusual attacks of tachycardia, Lancet, 2, 1013.

1931 Angina pectoris and coronary occlusion, Practitioner, 126, 652.

1932 Recurrent, subacute necrosis of pancreas, Guy's Hosp. Rep., 82, 269.

1935 Two cases of achalasia of cardia associated with chronic gastric ulcer, ibid., 85, 197.

1935 (with Camps, F. E.) Two cases of achalasia with pressure symptoms, Ibid., 85, 201.

1938 (and others) Two cases of Graves' disease with muscular atrophy, Ibid., 88, 117.

1939 Syphilis of the lungs, Quart. J. Med., 32, 381.

1941 (and others) Nature and treatment of effort syndrome, Proc. Roy. Soc. Med., 34, 541. 


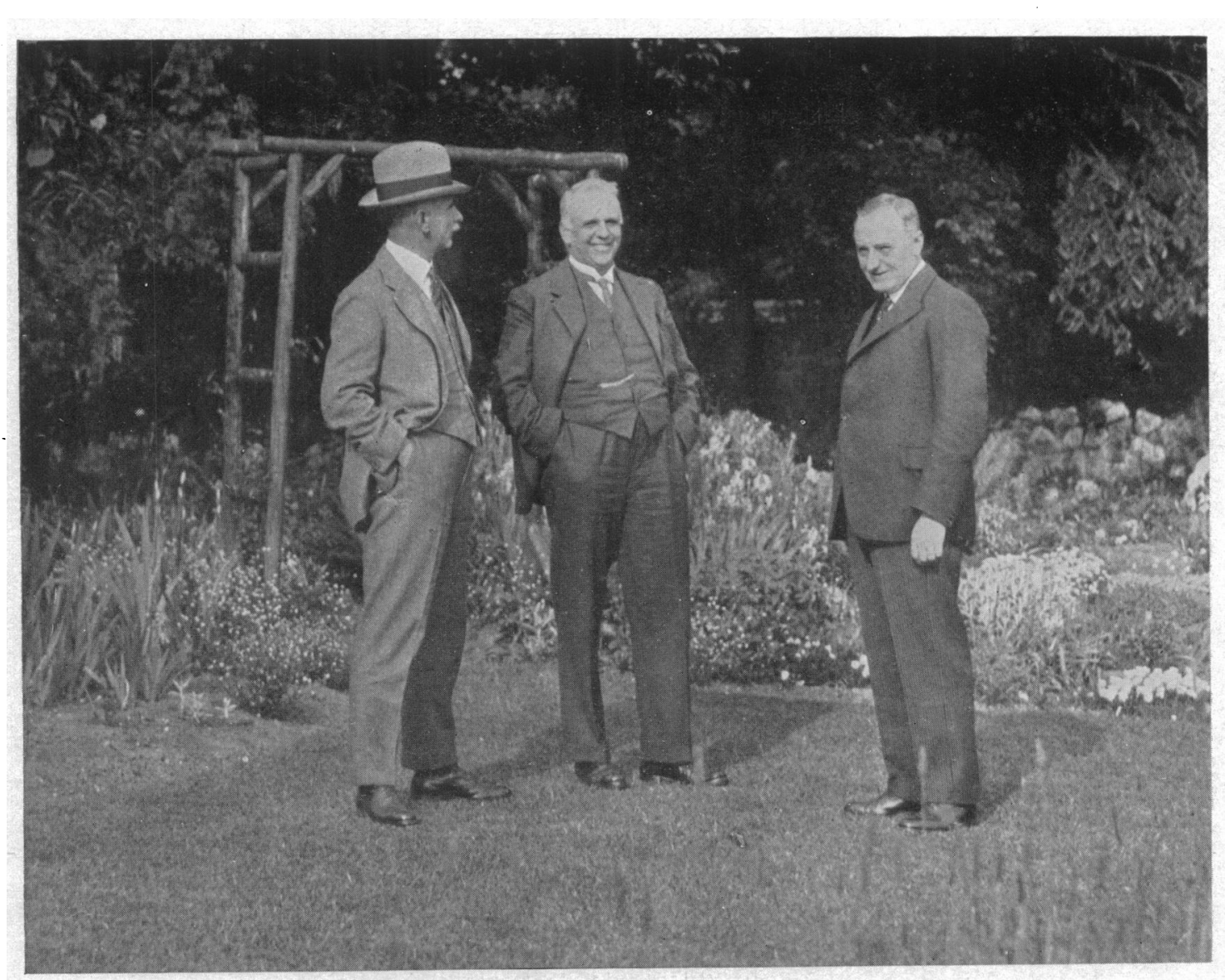

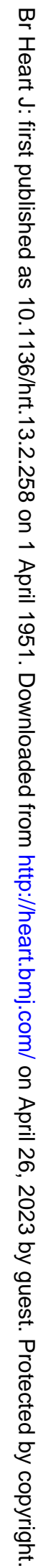




\section{NOTE BY EDITOR}

The Cardiac Society is indebted to John Hay for many things, and among them his excellent photographs of the early meetings of the Cardiac Club and its members. In this number it is our sad duty to publish memoirs of three of the senior members of the old club and it is thought that these informal snapshots will be a lively reminder of them.

In the group opposite, Gibson is shown standing on the right with Carey Coombs (centre) and Lewis (on the left), both in singularly characteristic attitudes; this was taken in John Hay's garden at Aigburth about 1928. Perhaps the picture of Gibson inserted in the memoir, taken when he was in a happy mood at one of the meetings, gives a better impression of him as a man.

The photograph of Cassidy (not published) fails to do justice to two of his great qualities, his friendly charm and his singularly unruffled demeanour in all circumstances, and Lady Cassidy adds that few photographs of him seemed good and has chosen a chalk drawing by Mrs. Campbell Dodgson.

In the lower picture opposite, Starling is shown with John Cowan. Except that they look perhaps older than they did at most meetings of the Society, everyone would regard these as characteristic expressions.

Starling was fond of the cartoon of himself which is shown below. It was drawn by Strube when Starling was working at Colchester during the 1914-18 war.

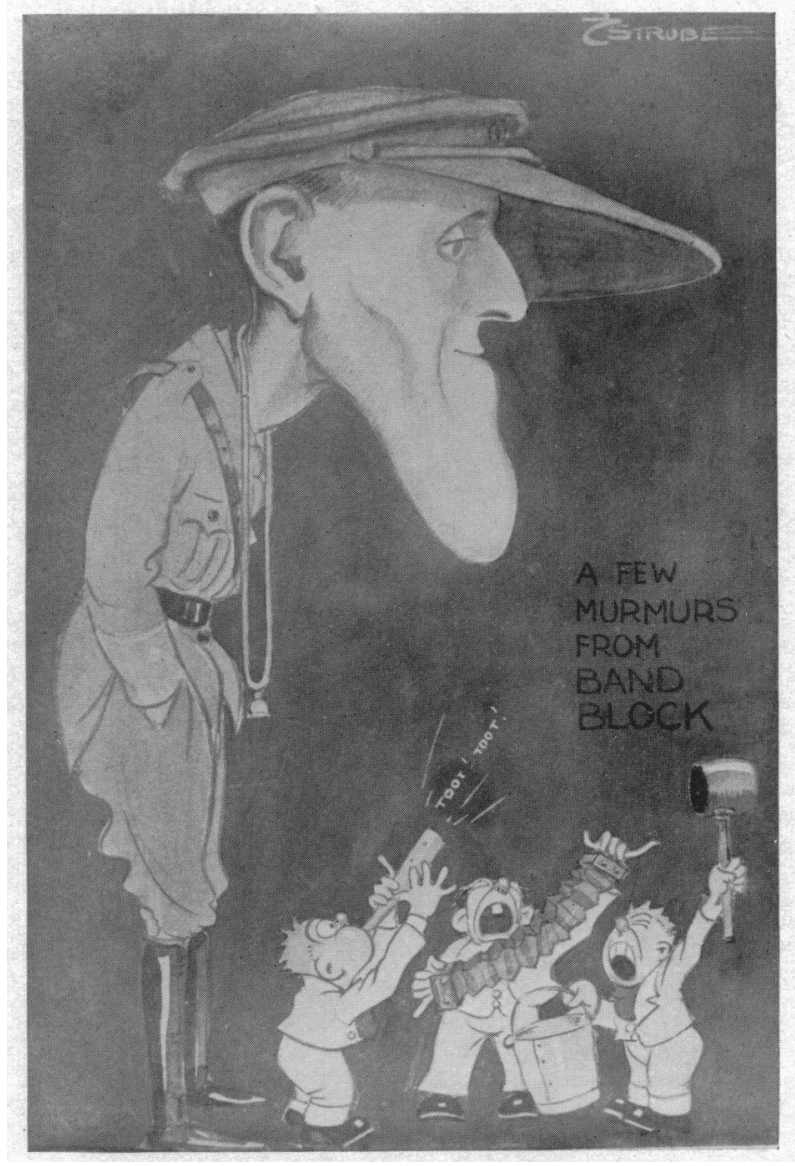

Starling. 